\title{
Panduan Biblioedukasi untuk Meningkatkan Sikap Respek Siswa SMP
}

\author{
Riza Aqilah Silmy*, Henny Indreswari, Muslihati \\ Universitas Negeri Malang, Jl. Semarang No. 5 Malang, Jawa Timur, Indonesia \\ *Penulis korespondensi, Surel: rizaaqilah.ra@gmail.com
}

Paper received: 25-8-2021; revised: 8-9-2021; accepted: 15-9-2021

\begin{abstract}
This research has the objective to obtain biblioeducation guidance to enhance respect among junior high students. The guidance consists of a series of activities and materials which are arranged systematically for counsellor and students. This development research adapted Borg and Gall steps. Tests required comprise early product and limited site tests. Early product test conducted by a Guidance and Counseling theory and media expert. While, limited site conducted by counsellor. The result assessment of this guidance book in terms of function reached each score 84, 87, 8, and 83 with average score $3,65,3,76,4$, and 3,60 which conclude as very functional. In terms of ease, it reached scores $66,64,28$, and 45 with average scores $3,47,3,37,4$, and 3,45 which conclude as very easy. In terms of precision, it reached scores 44, 41, 47, and 69 with average 3,38, 3,15, 3,91, and 3,63 which conclude as very precise. Based on theory expert I and II in terms of interest, it reached score 6 with average 3 which conclude as interesting. While based on media expert and personal usage, it reached score 12 and 8 with average score 4 which conclude as very interesting. Therefore, this guidance is allowed to be used by counsellor to provide Guidance and Counseling practice.
\end{abstract}

Keywords: biblioeducation; respect; junior high students

\begin{abstract}
Abstrak
Penelitian ini bertujuan menghasilkan panduan biblioedukasi untuk meningkatkan sikap respek pada siswa SMP. Panduan ini berisi serangkaian kegiatan dan materi yang disusun secara sistematis untuk konselor dan siswa. Penelitian pengembangan ini mengadaptasi langkah-langkah dari Borg dan Gall. Uji coba yang dilakukan terdiri dari uji coba produk awal dan uji coba lapangan terbatas. Uji coba produk awal ini dilakukan oleh ahli materi BK dan ahli media sedangkan uji coba lapangan terbatas dilakukan oleh konselor. Hasil penilaian buku panduan ini pada aspek kegunaan memperoleh skor total masing-masing 84, 87, 8, dan 83 dengan skor rata-rata 3,65, 3,76, 4, dan 3,60 termasuk dalam predikat sangat berguna. Pada aspek kemudahan memperoleh skor total 66, 64, 28, dan 45 dengan skor rata-rata 3,47, 3,37, 4, dan 3,45 termasuk dalam predikat sangat mudah. Pada aspek ketepatan memperoleh skor total 44, 41, 47, dan 69 dengan skor rata-rata 3,38, 3,15, 3,91, dan 3,63 termasuk dalam predikat sangat tepat. Pada ahli materi I dan II aspek kemenarikan memperoleh skor total 6 dengan skor rata-rata 3 termasuk dalam predikat menarik sedangkan pada ahli media dan pengguna masing-masing memperoleh skor total 12 dan 8 dengan rerata 4 termasuk dalam predikat sangat menarik. Dengan demikian, panduan ini dapat digunakan konselor dalam pemberian layanan bimbingan dan konseling.
\end{abstract}

Kata kunci: biblioedukasi; respek; siswa SMP

\section{Pendahuluan}

Pendidikan memiliki fungsi dan peran penting dalam usaha membentuk sikap dan pribadi siswa. Kedudukan pendidikan tidak hanya memberikan transformasi ilmu pengetahuan, namun juga diharapkan dapat memberikan bimbingan kepada siswa agar terbentuk sikap dan kepribadian yang baik. Salah satu agenda penting dalam proses pendidikan di sekolah adalah pengembangan sense of human dan sense of respect melalui penanaman nilai dan sikap saling menghargai, peduli pada orang lain dan penghormatan 
terhadap perbedaan (Widodo, 2018). Dalam situasi pendidikan perlu adanya suatu wadah untuk menampung dan menyelesaikan masalah-masalah siswa yang tidak dapat tertampung dan terselesaikan oleh guru. Bimbingan dan konseling salah satunya berperan dalam membantu siswa menyelesaikan permasalahan tersebut khususnya yang berkaitan dengan sense of human dan sense of respect.

Menurut Kamus Besar Bahasa Indonesia (KBBI) respek memiliki arti menghormati. Adapun menurut Shohihah (2020) menggambarkan respek sebagai sikap menghargai, menyukai, memberikan nilai positif terhadap diri, orang lain maupun lingkungan sekitar yang mendukung kehidupan manusia serta memuliakan dan mempedulikan hak-hak orang lain yang diwujudkan melalui perasaan dan tindakan. Hal ini berarti sikap respek digambarkan sebagai sikap penghormatan dan penghargaan terhadap diri, orang lain, maupun terhadap segala sesuatu yang berbeda dengan diri namun disikapi dengan damai.

Individu yang memiliki sikap respek tinggi akan menunjukkan sikap-sikap damai seperti menghargai pendapat orang lain, meminta bantuan dengan kata tolong tanpa ada unsur memerintah, berterima kasih setelah diberikan bantuan, meminta maaf saat melakukan kesalahan, menjaga flora dan fauna di lingkungan sekitar, memikirkan dengan matang segala keputusan yang diambil. Sedangkan individu yang memiliki sikap respek rendah cenderung menunjukkan sikap-sikap seperti mengacuhkan pendapat orang lain, rasis, mencaci maki orang lain, menyiksa hewan, merusak lingkungan, merendahkan orang lain, membohongi diri sendiri (Safitri, 2019). Adanya sikap hormat menjadikan seseorang terjaga untuk tidak merugikan apa yang harus dihargai. Oleh karena itu, melalui peningkatan sikap respek diharapkan akan tercipta suatu hubungan yang harmonis antar siswa. Namun, masalah yang terjadi berkaitan dengan respek ini masih menjadi sesuatu yang mengganggu di lingkungan sekitar.

Adapun kasus yang terjadi di SMP PGRI Wringinanom Gresik pada 10 Februari 2019 (Detik.com, 11/02/19). Pada mulanya salah seorang siswa merokok di dalam kelas dan seorang guru yang memergokinya akhirnya menegur. Siswa yang tidak terima ketika ditegur itupun lantas menantang gurunya dengan cara memegang kepala gurunya kemudian mendorong guru dan mencengkram kerah bajunya seakan-akan hendak memukul guru tersebut sambil memaki. Mirisnya teman-teman dari siswa yang mengetahui kejadian tersebut malah merekam dan menertawakan kejadian itu. Teman-teman dari siswa pun seakan tidak ada yang melerai kejadian tersebut.

Pada kasus lain misalnya sebuah berita yang viral mengenai penganiayaan siswa terhadap siswa lain yang terjadi di SMPN 18 Tangerang pada 5 Maret 2018 (Tempo.co, 2018). Kasus yang berawal saat tiga orang temannya dari kelas yang berbeda mendatangi siswa tersebut untuk mengajak bertanding futsal. Siswa yang diajak bermain futsal tersebut menolak karena lebih mementingkan fokus untuk belajar UTS. Tiga orang temannya tersebut lantas cekcok dan mengeroyok siswa tersebut menggunakan batu.

Hal ini diperkuat dengan banyak fakta di lapangan yang menunjukkan kasus rendahnya sikap respek yang dimiliki oleh siswa. Berdasarkan hasil wawancara yang dilakukan oleh peneliti terhadap salah satu konselor di SMPN 15 Malang pada bulan September 2018, diperoleh informasi bahwa sikap respek rendah siswa ini misalkan, mengganggu teman yang sedang mengerjakan tugas dengan cara mengajak ngobrol, meneriaki dan menertawakan siswa yang salah dalam menjawab pertanyaan, tidak mempedulikan teman yang memerlukan 
bantuan. Selain itu, sikap lain siswa terhadap gurunya ini misalnya ditunjukkan dengan cara kurang menyimak penjelasan guru, tidak mengerjakan tugas yang diberikan oleh guru, berjalan di depan guru tanpa permisi, meneriaki guru yang sedang berjalan, menggunjing guru yang kurang disukai, dan keluar kelas tanpa izin saat pelajaran berlangsung.

Upaya meningkatkan sikap respek pada siswa ini peran konselor merupakan faktor yang penting dalam membantu meningkatkan sikap respek melalui layanan bimbingan dan konseling. Penelitian yang pernah dilakukan untuk meningkatkan sikap respek di antaranya dilakukan oleh Tuanakotta (2018) dengan judul "Efektifitas Mendongeng untuk Meningkatkan Pemahaman Respek kepada Lingkungan pada Anak Usia 5-6 Tahun”, hasilnya didapatkan peningkatan nilai skor rata-rata antara nilai pretest dan posttest pemahaman anak tentang respek kepada lingkungan setelah diberikan intervensi mendongeng oleh pendidik. Semakin terampil pendidik dalam mendongeng maka semakin besar nilai rata-rata pemahaman anak. Peningkatan ini menandakan bahwa mendongeng cukup efektif untuk meningkatkan pemahaman anak usia 5-6 tahun tentang respek kepada lingkungan.

Sikap respek siswa juga dapat ditingkatkan melalui pemberian layanan informasi. Menurut Thohirin (2008) layanan informasi ini bertujuan agar individu mengetahui dan menguasai informasi yang selanjutnya dimanfaatkan untuk keperluan sehari-hari dirinya dan untuk perkembangan dirinya. Dalam layanan informasi ini terdapat suatu teknik yang dapat digunakan salah satunya biblioedukasi. Dalam hal ini, konselor dapat menggunakan biblioedukasi sebagai metode untuk meningkatkan keterampilan positif khususnya meningkatkan sikap respek. Biblioedukasi ini merupakan istilah yang dipakai untuk memberikan penjelasan atau metode yang dikembangkan dalam bentuk bahan bacaan sebagai upaya pencegahan maupun peningkatan perilaku tertentu. Menurut Sukamta (dalam Ahmad \& Dini, 2017) tujuan dari biblioedukasi adalah mengetahui informasi yang ada dalam bahan bacaan, sehingga secara umum dapat membentuk tingkah laku dan secara khusus dapat membentuk sikap, serta persepsi. Dengan kata lain, biblioedukasi ini memiliki kelebihan seperti seseorang bisa mengenali dirinya karena informasi dan pengetahuan yang diperoleh dari kegiatan membaca menjadi masukan dalam memecahkan masalah seseorang.

Penelitian lyang dilakukan oleh Yunitasari (2018) menunjukkan bahwa adanya perbedaan skor antara sebelum dilakukan biblioedukasi dan sesudah dilakukan biblioedukasi. Teknik biblioedukasi yang dilakukan berpengaruh positif terhadap siswa kelas VII SMP Negeri 32 Surabaya yang mengalami percaya diri rendah. Pada awalnya subjek dalam penelitian ini memiliki sikap kurang percaya diri yang ditunjukkan dengan sikap tidak berani berbicara di depan umum, tidak berani mengungkapkan pendapat, dan tidak yakin terhadap kemampuan yang dimiliki. Setelah melakukan biblioedukasi tersebut, siswa terbantu menyelesaikan masalah yang dihadapi dan siswa tertarik untuk mengikuti perilaku percaya diri yang ada pada tokoh di dalam cerita tersebut, sehingga dapat disimpulkan bahwa pemberian perlakuan teknik biblioedukasi dapat meningkatkan percaya diri.

Hal ini diperkuat dengan penelitian yang pernah dilakukan oleh Safitri (2021) hasilnya menunjukkan bahwa biblioedukasi efektif dilakukan untuk meningkatkan kesadaran respek pada siswa SD. Hal ini dibuktikan dengan adanya perbedaan hasil pretest dan post test. Pada saat post test terjadi peningkatan skor hingga mencapai kriteria maksimal yaitu sangat tinggi pada seluruh subjek. Hal ini menunjukkan bahwa kesadaran respek siswa SD dapat ditingkatkan melalui biblioedukasi. 
Berdasarkan kondisi yang terjadi terkait upaya peningkatan sikap respek siswa, konselor membutuhkan media yang tepat untuk meningkatkan sikap respek siswa. Oleh karena itu penelitian ini akan mengembangkan panduan untuk meningkatkan sikap respek siswa SMP melalui biblioedukasi dan selanjutnya panduan ini akan diberikan kepada konselor di sekolah. Teknik biblioedukasi ini dipilih dengan alasan teknik ini dinilai efektif untuk meningkatkan berbagai sikap berdasarkan pemaparan penelitian sebelumnya. Dalam biblioedukasi ini terkandung pesan moral pada bahan bacaan, sehingga diharapkan pesan moral tersebut dapat mempengaruhi pembaca untuk meningkatkan sikap respeknya.

\section{Metode}

Penelitian dan pengembangan ini secara spesifik menggunakan metode penelitian pengembangan (research and development). Metode Research and Development (R\&D) menurut Borg \& Gall (1983), yaitu penelitian yang digunakan untuk mengembangkan dan memvalidasikan alat sebagai salah satu produk penelitian. Langkah-langkah dalam model pengembangan ini meliputi pengumpulan data, perencanaan, mengembangkan produk, uji coba produk awal (uji coba ahli), revisi produk, uji coba pengguna, dan revisi produk akhir. Subjek penelitian dan pengembangan ini adalah siswa SMP Negeri 15 Malang.

Tahap pertama merupakan tahap pengumpulan data. Pada tahap ini dilakukan penentuan masalah penelitian, studi literatur, wawancara dan need assessment. Penentuan masalah bermula dari adanya suatu fenomena di lapangan, yaitu adanya beberapa siswa di salah satu SMP Negeri di Malang bersikap tidak respek terhadap temannya dan terhadap lingkungan seperti berkelahi dan menyaksikan perkelahian dengan diam, keluar kelas saat jam pelajaran berlangsung tanpa ijin, serta meletakkan piring bekas pakai di lantai kantin. Setelah menentukan masalah, peneliti melakukan studi literatur yang merupakan kegiatan mengkaji sumber bacaan. Studi literatur dilakukan dengan mengkaji bahan-bahan pustaka yang relevan dengan potensi masalah yang telah dipilih dalam penelitian pengembangan ini. Selanjutnya peneliti melakukan need assessment dengan cara menyebarkan angket kepada siswa dan wawancara dengan konselor. Berdasarkan analisis angket kebutuhan tersebut, maka dapat disimpulkan bahwa peserta didik di SMP Negeri 15 Malang membutuhkan panduan biblioedukasi sebesar 75\%. Hal ini juga ditandai dengan hasil analisis angket kebutuhan yang menunjukkan bahwa siswa melakukan sikap tidak respek sebesar 64,7\%. Proses wawancara dilakukan dengan konselor SMPN 15 Malang dengan membuat pedoman wawancara.

Tahap kedua merupakan tahap perencanaan. Kegiatan yang akan dilakukan dalam tahap perencanaan ini adalah pembuatan RPLBK (Rencana Pelaksanaan Layanan Bimbingan dan Konseling) dengan menentukan topik dasar, strategi, rumusan tujuan yang hendak dicapai, merumuskan komponen layanan, bidang layanan, fungsi layanan, sasaran layanan, materi layanan, alokasi waktu, metode atau teknik, media atau alat yang disesuaikan dengan kegiatan bimbingan, dan menyusun desain atau langkah-langkah penelitian dan pengembangan.

Tahap ketiga merupakan tahap pengembangan produk. Dalam mengembangkan bentuk produk, kegiatan yang dilakukan peneliti adalah mengembangkan kerangka materi yang sudah disusun, serta menyusun isi dari panduan biblioedukasi dan menyusun alat evaluasi produk yang dikembangkan. Materi yang dikembangkan dalam panduan bimbingan dengan teknik biblioedukasi untuk meningkatkan sikap respek pada siswa SMP memuat cerita-cerita tentang sikap respek meliputi, aspek respek terhadap diri sendiri, respek terhadap orang lain, dan respek terhadap tempat atau benda. Aspek respek tersebut digunakan sebagai dasar 
mengembangkan konten cerita sebagai materi bahan bacaan dalam meningkatkan sikap respek. Alat evaluasi produk yang dikembangkan berupa instrumen uji ahli dan instrumen uji calon pengguna produk (konselor). Alat evaluasi produk digunakan untuk mengetahui kegunaan, ketepatan, kemudahan, kemenarikan produk yang dihasilkan.

Tahap keempat yaitu uji coba produk awal atau biasa disebut sebagai uji ahli. Uji ahli ini dilakukan dengan tenaga ahli yang sudah berpengalaman untuk menilai produk yang dikembangkan, sehingga dapat diketahui kelemahan dan kekuatan produk yang dihasilkan. Pada tahap uji ahli dilakukan evaluasi dan penilaian selain untuk mengetahui bagaimana kegunaan, kemudahan, ketepatan dan kemenarikan produk yang dikembangkan. Uji ahli dilakukan oleh ahli materi dan ahli media. Peneliti melakukan uji ahli materi dengan dosen bimbingan dan konseling melalui proses validitas terhadap kualitas dan isi dari materi buku panduan. Selain itu memberikan saran dan masukan terhadap isi materi sesuai dengan sasaran yaitu siswa SMP. Selanjutnya peneliti melakukan uji ahli media dilakukan untuk menguji keberterimaan dari buku panduan guna melihat kemenarikan dari produk yang dikembangkan. Misalnya desain dari panduan, jenis huruf, bahasa, warna, dan lainnya. Sebelumnya, untuk dapat menentukan interpretasi dari hasil validasi ahli dan calon pengguna produk, maka terlebih dahulu menentukan rentangan skor atau interval kelas. Hasil penilaian dari validasi ahli dan calon pengguna produk ini akan dianalisis menggunakan data bersifat kuantitatif dan kualitatif. Data kuantitatif dianalisis menggunakan rumus rerata (mean), sedangkan data kualitatif dianalisis menggunakan analisis data model Miles dan Huberman, serta lembar kritik dan saran secara umum untuk dijadikan acuan dalam memperbaiki atau merevisi produk panduan biblioedukasi agar tepat, dan efektif untuk meningkatkan sikap pada siswa SMP.

Tahap kelima yaitu revisi produk utama. Revisi produk dilakukan untuk memperbaiki kelemahan produk yang dikembangkan. Kelemahan produk diperbaiki dengan berpatokan hasil penilaian dan saran oleh ahli materi dan ahli media. Revisi produk ini bertujuan agar panduan yang dikembangkan menjadi layak dari segi teoritis dan ketepatan media yang dikembangkan.

Tahap keenam yaitu uji coba lapangan utama atau bisa disebut dengan uji calon pengguna (konselor). Uji coba ini dilakukan untuk menguji produk yang telah divalidasi oleh ahli. Uji calon pengguna produk dilakukan pada konselor SMPN 15 Malang. Konselor memberikan penilaian dengan mengisi format penilaian uji calon pengguna dan memberikan saran atau masukan untuk perbaikan produk. Penilaian ini akan memperkuat keberterimaan produk yang dikembangkan.

Tahap ketujuh yaitu revisi produk operasional. Revisi produk dilakukan berdasarkan hasil penilaian calon pengguna produk yaitu konselor SMPN 15 Malang. Hasil dari revisi diharapkan merupakan pendukung yang kuat sehingga akan menjadikan produk yang sesuai dengan kebutuhan pengguna produk dan menarik pengguna produk. Selain itu, produk yang direvisi akan dijadikan pendukung yang kuat atas kelayakan produk ini. 


\section{Hasil dan Pembahasan}

\subsection{Hasil}

Penelitian dan pengembangan ini menghasilkan produk berupa panduan konselor dan buku kegiatan siswa mengenai pengembangan biblioedukasi untuk meningkatkan sikap respek pada siswa SMP. Berdasarkan hasil validasi ahli materi bimbingan dan konseling pada ahli I dan II pada aspek kegunaan diperoleh skor total masing-masing 84 dan 87 dengan skor rata-rata 3,65 dan 3,76 termasuk dalam predikat sangat berguna. Pada aspek kemudahan memperoleh skor total 66 dan 64 dengan rata-rata 3,47 dan 3,37 termasuk dalam predikat sangat mudah. Pada aspek ketepatan memperoleh skor total 44 dan 41 dengan rata-rata 3,38 dan 3,15 termasuk dalam predikat sangat tepat. Pada aspek kemenarikan memperoleh skor total masing-masing 6 dengan rata-rata 3 termasuk dalam predikat menarik. Adapun masukan berupa kritik dan saran dari ahli I adalah panduan harus menggunakan istilah yang konsisten yaitu respek (dalam bahasa Indonesia), pertanyaan belum sepenuhnya mengacu pada tujuan khusus, dan skala respek harus dilengkapi dengan panduan penskoran yang jelas karena belum nampak petunjuk mengenai item favourable dan unfavourable serta nominal skornya sehingga bisa mempersulit kinerja konselor dalam melakukan skoring. Pada ahli II memperoleh masukan bahwa panduan masih diperlukan perbaikan cara penulisannya dan perlu ditambahkan evaluasi proses.

Berdasarkan hasil validasi ahli media pada aspek kegunaan memperoleh skor total 8 dengan rata-rata 4 termasuk dalam predikat sangat berguna. Pada aspek kemudahan memperoleh skor total 28 dengan rata-rata 4 termasuk dalam predikat sangat mudah. Pada aspek ketepatan memperoleh skor total 47 dengan skor rata-rata 3,91 termasuk dalam predikat sangat tepat. Pada aspek kemenarikan memperoleh skor total 12 dengan rata-rata 4 termasuk dalam predikat sangat menarik. Adapun masukan dari ahli media ini desain visual maupun grafis serta penataan konten dan struktur sajiannya sudah cukup bagus dan layak untuk diimplementasikan, dapat ditambahkan tautan link ke digital online resources.

Hasil validasi pengguna (konselor) pada aspek kegunaan memperoleh skor total 83 dengan rata-rata 3,60 termasuk dalam predikat sangat berguna. Pada aspek kemudahan memperoleh skor total 45 dengan rata-rata 3,45 termasuk dalam predikat sangat mudah. Pada aspek ketepatan memperoleh skor total 69 dengan rata-rata 3,63 termasuk dalam predikat sangat tepat. Pada aspek kemenarikan memperoleh skor total 8 dengan rata-rata 4 termasuk dalam predikat sangat menarik. Adapun masukan dari pengguna (konselor) ini adalah penekanan judul dan isi lebih baik ukuran font dibedakan.

Dapat disimpulkan bahwa produk ini telah berterima secara teoritis melalui validasi ahli materi dan media serta berterima secara praktis melalui validasi calon pengguna produk. Hasil penelitian menunjukkan bahwa biblioedukasi untuk meningkatkan sikap respek pada siswa SMP telah berterima dan dapat digunakan sebagai layanan bimbingan di sekolah. Dalam hal ini revisi produk dilakukan untuk memperbaiki kekurangan yang terdapat dalam panduan biblioedukasi ini, sehingga panduan dapat digunakan secara maksimal dalam memberikan layanan bimbingan dan konseling di sekolah. Data kualitatif yang didapatkan dari penilaian produk ini merupakan data berupa kritik, saran, dan masukan dari ahli materi bimbingan dan konseling, ahli media, serta calon pengguna produk. Dari hasil kritik dan saran yang didapatkan, peneliti menganalisis data kualitatif tersebut menggunakan model Miles dan 
Huberman yang analisis datanya terbagi menjadi 3 tahap, yaitu reduksi data, penyajian data, dan penarikan kesimpulan yang selanjutnya akan dijadikan landasan dalam melakukan revisi produk pengembangan.

Reduksi data adalah proses merangkum, memilih hal-hal yang pokok, memfokuskan pada hal-hal yang penting, mencari tema dan polanya. Dalam penelitian ini, peneliti mendapatkan beberapa kritik dan saran mengenai penggunaan istilah yang konsisten yaitu respek (dalam bahasa Indonesia), pertanyaan refleksi belum sepenuhnya mengacu pada tujuan khusus, dan skala respek harus dilengkapi dengan panduan penskoran yang jelas karena belum nampak petunjuk mengenai item favourable dan unfavourable serta nominal skornya sehingga bisa mempersulit kinerja konselor dalam melakukan skoring, perlunya dilakukan evaluasi proses, perbaikan cara penulisan, dan penambahan tautan atau link ke digital online resources.

Pada penyajian data, kritik dan saran yang didapat pada validasi ahli dan calon pengguna produk dapat dijabarkan yaitu panduan biblioedukasi mendapat saran terkait dengan penggunaan istilah yang konsisten yaitu respek (dalam bahasa Indonesia) pada judul sehingga tetap konsisten antara judul dengan isi buku panduan, pertanyaan refleksi harus sepenuhnya mengacu pada tujuan khusus karena penyajian pertanyaan refleksi masih bersifat umum, dan untuk skala respek harus dilengkapi dengan panduan penskoran yang jelas karena belum nampak petunjuk mengenai item favourable dan unfavourable serta nominal skornya sehingga bisa mempersulit kinerja konselor dalam melakukan skoring, perlu juga dilakukan evaluasi proses, cara penulisan masih terdapat beberapa kesalahan seperti kesalahan penulisan kata dan penggunaan tanda baca, serta optimalisasi panduan dengan penambahan tautan atau link ke digital online resources supaya mudah diakses oleh pembaca lain.

Dari beberapa kategori kritik dan saran yang didapat dalam validasi ahli dan calon pengguna produk, dapat disimpulkan bahwa panduan biblioedukasi mendapat kritik dan saran dari segi kelengkapan dan kesesuaian. Jadi, meskipun secara kuantitatif produk panduan biblioedukasi untuk meningkatkan sikap respek mendapatkan interpretasi "sangat berterima sebagai media layanan bimbingan di sekolah", namun ada beberapa hal yang perlu diperbaiki dalam rangka menyempurnakan produk ini.

\subsection{Pembahasan}

Sikap respek merupakan sikap menghormati dan menghargai diri, orang lain, maupun tempat atau benda di lingkungan sekitar yang ditunjukkan dengan cara seperti menerapkan pola hidup sehat, menyempatkan belajar, saling bertegur sapa dengan orang lain yang dikenal, bersedia saling memaafkan kesalahan, bertutur kata jujur dan santun, memberikan bantuan kepada orang lain, membiasakan diri meminta izin, menerima perbedaan bahasa, dialek maupun SARA antar teman, bersikap tenang ketika berada di tempat ibadah, bertamu ke rumah orang lain dengan sopan, menjaga benda titipan, dan menggunakan fasilitas umum dengan bijak. Dengan kata lain, respek ini tidak hanya berhubungan dengan diri individu namun juga kepada orang lain yang keduanya sama penting untuk membangun pribadi berkarakter baik.

Sikap tidak respek di lapangan terjadi pada rata-rata mereka yang masih remaja. Dalam penelitian ini, sasaran tempat penelitian yaitu SMP, khususnya SMP Negeri 15 Malang. Adanya beberapa siswa di SMP Negeri 15 Malang yang bersikap tidak respek terhadap temannya dan 
terhadap lingkungan seperti berkelahi dan menyaksikan perkelahian namun diam dan tidak mau melerai, keluar kelas saat jam pelajaran berlangsung tanpa ijin, serta meletakkan piring bekas pakai di lantai kantin. Sikap respek ini merupakan faktor yang paling besar pengaruhnya dalam interaksi antar individu di lingkungan masyarakat. Sikap respek ini sudah semestinya terbentuk dan terjaga dengan baik agar interaksi antar manusia menjadi lebih baik. selain itu, sikap respek sangat penting dalam menciptakan hubungan yang harmonis dan terarah. Seperti yang dijelaskan oleh Kant (dalam Eliasa, 2011) bahwa seseorang perlu dihormati dan menghormati orang lain sebagai pribadi, dan penerapan moral dalam hal yang lebih luas, tidak hanya manusia namun juga lingkungan alam.

Sebagai dasar pertimbangan untuk melakukan penelitian, maka peneliti memperoleh data tentang tingkat sikap respek yang sering dilakukan oleh siswa SMP Negeri 15 Malang hingga mengakibatkan perilaku destruktif. Isi panduan biblioedukasi ini dikembangkan berdasarkan teori respek menurut Palmer yang setiap dua bacaan ceritanya mengandung satu aspek respek terhadap diri, orang lain, dan benda atau tempat. Produk hasil penelitian dan pengembangan ini berupa panduan biblioedukasi untuk meningkatkan sikap respek bagi konselor dan buku kegiatan bagi siswa. Pengembangan produk ini melalui proses sistematis sesuai dengan prosedur penelitian dan pengembangan Borg \& Gall (1983) yang telah disesuaikan dengan kebutuhan penelitian dan pada akhirnya menghasilkan produk akhir berupa panduan biblioedukasi yang telah berterima dan dapat digunakan sebagai media layanan bimbingan di sekolah.

Panduan biblioedukasi ini telah disesuaikan dengan SKKPD siswa SMP, didesain menarik, melalui uji validasi ahli dan calon pengguna produk, serta telah direvisi, sehingga menghasilkan panduan biblioedukasi yang berterima. Isi buku panduan bagi konselor diantaranya terdapat kata pengantar; daftar isi; pendahuluan; petunjuk penggunaan panduan; topik dasar yang meliputi pertemuan 1 sampai 5; instrumen sikap respek; evaluasi diri siswa; lembar kontrak diri siswa; dan daftar rujukan. Isi panduan dalam buku kegiatan siswa terdapat kata pengantar; daftar isi; petunjuk penggunaan buku kegiatan siswa; prosedur; topik dasar, bacaan cerita dari pertemuan 1 sampai 4; evaluasi diri siswa; kontrak diri siswa; serta daftar rujukan.

Dalam menilai aspek keberterimaan produk pengembangan ini, kriteria yang digunakan meliputi aspek ketepatan, kegunaan, kemudahan, dan kemenarikan. Aspek-aspek ini dikembangakan menjadi instrumen penilaian validasi ahli materi, ahli media, dan calon pengguna produk (konselor). Hasil dari penilaian aspek keberterimaan produk pengembangan panduan biblioedukasi ini dianalisis menggunakan rumus mean.

Panduan biblioedukasi juga berterima secara teoritis maupun praktis karena telah divalidasi dan direvisi oleh ahli materi, ahli media, dan calon pengguna produk. Ahli materi dan calon pengguna produk memberikan penilaian berdasarkan substansi produk secara keseluruhan, sedangkan ahli media memberikan penilaian mengenai desain produk secara keseluruhan. Hasil validasi ahli materi I dan II pada aspek kegunaan diperoleh skor total masing-masing 84 dan 87 dengan skor rata-rata 3,65 dan 3,76 termasuk dalam predikat sangat berguna. Pada aspek kemudahan memperoleh skor total 66 dan 64 dengan rata-rata 3,47 dan 3,37 termasuk dalam predikat sangat mudah. Pada aspek ketepatan memperoleh skor total 44 dan 41 dengan rata-rata 3,38 dan 3,15 termasuk dalam predikat sangat tepat. Pada aspek kemenarikan memperoleh skor total masing-masing 6 dengan rata-rata 3 termasuk dalam 
predikat menarik. Hasil validasi ahli media pada aspek kegunaan memperoleh skor total 8 dengan rata-rata 4 termasuk dalam predikat sangat berguna. Pada aspek kemudahan memperoleh skor total 28 dengan rata-rata 4 termasuk dalam predikat sangat mudah. Pada aspek ketepatan memperoleh skor total 47 dengan skor rata-rata 3,91 termasuk dalam predikat sangat tepat. Pada aspek kemenarikan memperoleh skor total 12 dengan rata-rata 4 termasuk dalam predikat sangat menarik. Validasi pengguna (konselor) pada aspek kegunaan memperoleh skor total 83 dengan rata-rata 3,60 termasuk dalam predikat sangat berguna. Pada aspek kemudahan memperoleh skor total 45 dengan rata-rata 3,45 termasuk dalam predikat sangat mudah. Pada aspek ketepatan memperoleh skor total 69 dengan rata-rata 3,63 termasuk dalam predikat sangat tepat. Pada aspek kemenarikan memperoleh skor total 8 dengan rata-rata 4 termasuk dalam predikat sangat menarik. Dengan demikian, produk panduan biblioedukasi dapat dipercaya dari aspek keberterimaan secara praktis.

Panduan bibiblioedukasi ini memenuhi kelayakan berdasarkan validasi ahli materi dan calon pengguna produk (konselor), karena materi yang terdapat dalam buku panduan konselor maupun buku kegiatan siswa telah disesuaikan dengan angket need assessment. Panduan biblioedukasi ini dinilai tepat digunakan oleh konselor sebagai salah satu metode untuk meningkatkan sikap respek pada siswa SMP karena masalah atau konflik yang disajikan dalam bacaan cerita biasa dialami siswa SMP dan merupakan masalah yang terjadi dalam kehidupan sehari-hari.

Bacaan dalam biblioedukasi memuat pesan-pesan dari penulis yang ditujukan kepada pembaca. Dalam hal ini, penulis dapat mengirim pesan-pesan tentang sikap respek dan bahayanya apabila sikap respek sangat rendah dikalangan para siswa. Melalui bacaan tersebut, penulis juga menyisipkan cara berinteraksi dalam pergaulan yang sesuai dengan adab dan norma yang ada, sehingga sikap respek dapat ditingkatkan. Adanya peningkatan sikap respek dalam keseharian siswa maka dapat menghindarkan siswa dari sikap yang tidak bertanggungjawab seperti halnya perundungan.

Berbagai penelitian yang berkaitan dengan biblioedukasi dan sikap respek ini telah dilakukan. Studi yang dilakukan oleh Pratiwi (dalam Fiftiani, 2013) menunjukkan bahwa sebanyak 80\% siswa SMP Negeri se-Kabupaten Banyumas menyukai kegiatan membaca karyakarya sastra terutama cerpen. Hal ini selaras dengan penelitian ini yaitu biblioedukasi sangat dibutuhkan oleh siswa. Adapun data yang dikumpulkan dari SMPN 15 Malang menunjukkan siswa-siswa menyukai membaca bahan bacaan seperti cerpen dan cerita-cerita dari novel toon maupun internet, selain itu, siswa juga beranggapan bahwa kegiatan membaca merupakan kebutuhan diri dalam menambah pengalaman.

Penelitian lain oleh Ahmad \& Dini (2017) menunjukkan bahwa ada pengaruh penerapan biblioedukasi terhadap rasa rendah diri pada siswa kelas IX IPS 3 di SMAN 8 Mataram. Hal ini dibuktikan dengan data hasil observasi sebelum dan sesudah menggunakan teknik biblioedukasi ini ada pengaruh maupun perubahan pada rasa rendah diri siswa. Berdasarkan hasil penelitiannya, ia menunjukkan bahwa pada awalnya kemampuan belajar secara aktif siswa sering terganggu oleh perasaan, pikiran, persepsi, wawasan dan sikap yang tidak objektif, sempit, terkukung, serta tidak efektif. Setelah melalui layanan bimbingan kelompok berupa biblioedukasi hal-hal yang mengganggu atau yang menghimpit perasaan dapat diungkapkan, dilontarkan, serta diringankan. 
Penelitian lain yang dilakukan oleh Yunitasari (2018) menunjukkan bahwa adanya perbedaan skor antara sebelum dilakukan biblioedukasi dan sesudah dilakukan biblioedukasi. Teknik biblioedukasi yang dilakukan berpengaruh positif terhadap siswa kelas VII SMP Negeri 32 Surabaya yang mengalami percaya diri rendah. Pada awalnya subjek dalam penelitian ini memiliki sikap kurang percaya diri yang ditunjukkan dengan sikap tidak berani berbicara di depan umum, tidak berani mengungkapkan pendapat, dan tidak yakin terhadap kemampuan yang dimiliki. Setelah melakukan biblioedukasi tersebut, siswa terbantu menyelesaikan masalah yang dihadapi dan siswa tertarik untuk mengikuti perilaku percaya diri yang ada pada tokoh di dalam cerita tersebut, sehingga dapat disimpulkan bahwa pemberian perlakuan teknik biblioedukasi dapat meningkatkan percaya diri.

Hal ini diperkuat dengan penelitian yang pernah dilakukan oleh Safitri (2020) hasilnya menunjukkan bahwa biblioedukasi efektif dilakukan untuk meningkatkan kesadaran respek pada siswa SD. Hal ini dibuktikan dengan adanya perbedaan hasil pretest dan post test. Pada saat post test terjadi peningkatan skor hingga mencapai kriteria maksimal yaitu sangat tinggi pada seluruh subjek. Hal ini menunjukkan bahwa kesadaran respek siswa SD dapat ditingkatkan melalui biblioedukasi. Penelitian terdahulu yang telah dipaparkan berkaitan dengan biblioedukasi tersebut dapat disimpulkan bahwa teknik ini efektif untuk diterapkan

Penelitian ini belum sampai pada tahap melakukan uji kelompok kecil, sehingga penelitian ini bisa dilanjutkan dengan penelitian eksperimen untuk mengetahui keefektifan panduan biblioedukasi dalam membantu siswa meningkatkan sikap respek guna diperoleh hasil yang lebih akurat. Produk ini memiliki keunggulan dan keterbatasan. Keunggulan produk pengembangan panduan biblioedukasi ini yaitu memuat materi yang telah disesuaikan dengan kebutuhan siswa, instrumen sikap respek sebagai alat evaluasi layanan, produk pengembangan dapat digunakan sebagai sumber belajar bagi siswa secara mandiri dan menarik, bersifat fleksibel, serta telah dilakukan validasi ahli dan calon pengguna produk. Keterbatasan produk pengembangan panduan biblioedukasi ini yaitu muatan materi hanya berfokus kepada materi sikap respek yang meliputi sikap respek terhadap diri, respek terhadap orang lain, dan respek terhadap tempat maupun benda. Need assessment yang dilakukan hanya sebatas 30 orang yang masing-masing 5 orang dari 6 kelas, yakni kelas VIII-A sampai VIII-F SMP Negeri 15 Malang. Hal ini dikarenakan kelas VIII merupakan kelas transisi atau kelas tengah yang siswanya menjadi senior sekaligus junior. Adapun observasi yang dilakukan peneliti selama KPL (Kajian dan Praktik Lapangan) di SMP Negeri 15 Malang juga diperoleh hasil bahwa siswa-siswi yang sering melakukan sikap tidak respek adalah kelas VIII, sehingga peneliti memilih secara acak atau random kelas yang akan dijadikan subjek penelitian.

\section{Simpulan}

Berdasarkan penelitian dan pembahasan yang telah dikemukakan, dapat disimpulkan bahwa panduan biblioedukasi ini terdiri dari dua buku, yaitu panduan untuk konselor dan buku kegiatan siswa Hasil uji ahli materi, uji ahli media, dan uji pengguna (konselor) terhadap produk panduan untuk konselor dan buku kegiatan untuk siswa memenuhi kriteria keberterimaan produk secara teoritis dan praktis baik dari segi ketepatan, kegunaan, kemudahan, dan kemenarikan. Panduan biblioedukasi berfungsi sebagai salah satu alat atau media yang dapat digunakan konselor dalam memberikan layanan bimbingan di sekolah, terkait dengan sikap respek. Dalam penerapannya, perlu dipahami dan dipelajari terlebih 
dahulu serta lebih berhati-hati dalam menginterpretasikan isi dari panduan biblioedukasi ini, karena panduan ini belum sampai pada tahap uji keefektifan atau penelitian eksperimen.

\section{Daftar Rujukan}

Ahmad, H., \& Dini, K. (2018). Pengaruh Teknik Biblio Edukasi Terhadap Rasa Rendah Diri Pada Kelas Xi Di Sma Negeri 8 Mataram. Realita: Jurnal Bimbingan dan Konseling, 2(1). 194-207.

Borg, W. D. \& Gall, M. D. (1983). Educational Research Third Edition. New York: Longman Inc.

Detik. (2019). Kisah Bocah di Gresik Tantang Guru Hingga Bersujud Minta Maaf. Retrieved Februari 19, 2019, dari https://news.detik.com/berita-jawa-timur/d-4422329/kisah-bocah-smp-di-gresik-tantang-guru-hinggabersujud-minta-maaf.

Eliasa, E. I. (2011). Bibliotherapy as a Meaningful Treatment. Yogyakarta: Universitas Negeri Yogyakarta.

Fiftiani, A. (2013). Resepsi Siswa Kelas VII SMP Negeri di Kabupaten Banyumas Terhadap Cerpen Remaja "Maafkan Aku Ibu" Karya Herawati. Yogyakarta: Fakultas Bahasa dan Seni UNY.

Hambali. (2018). Bullying Siswa SMP di Tangsel Korban Dipukul Pakai Batu. Retrieved Maret 07, 2018, Dari https://www.google.com/amp/s/megapolitan.okezone.com/amp/2018/03/07/338/1869092/bullying-siswasmp-di-tangsel-korban-dipukul-pakai-batu.

KBBI Daring (Kamus Besar Bahasa Indonesia Dalam Jaringan). 2019. (Online), (https://kbbi.kemdikbud.go.id), diakses 12 Juni 2019.

Safitri, I. H. (2019). Efektivitas Biblioedukasi untuk Meningkatkan Kesadaran Respek Siswa SD. Skripsi tidak diterbitkan. Malang: FIP UM.

Safitri, I. F., Handarini, D. M., \& Mappiare-AT, A. (2021). Meningkatkan Kesadaran Respek Siswa Sekolah Dasar dengan Biblioedukasi. Buletin Konseling Inovatif, 1(1). 1-6

Shohihah, R. (2020). Sikap Respect Siswa SMP di Kecamatan Bandung Kabupaten Tulungagung (Penelitian Survey). Skripsi diterbitkan. Kediri: Fakultas Ushuluddin Adab dan Dakwah IAIN Tulungagung.

Tempo. (2018). Tiga Siswa SMPN 18 Terlibat Pengeroyokan Dikenakan Skorsing. Retrieved Maret 9, 2018, dari https://www.google.com/amp/s/metro.tempo.co/amp/1067856/tiga-siswa-smpn-18-terlibatpengeroyokan-dikenakan-skorsing.

Tohirin. (2008). Bimbingan Konseling di Sekolah dan Madrasah (berbasis integrasi). Jakarta: Raja Grafindo Persada.

Tuanakotta, M. \& Indianti, W. (2018). Efektivitas Mendongeng untuk Meningkatkan Pemahaman Respek Kepada Lingkungan pada Anak Usia 5-6 Tahun. Jurnal Intervensi Psikologi, 10(2), 83-102.

Widodo, H. (2018). Pengembangan Respect Education Melalui Pendidikan Humanis Religius di Sekolah. Lentera Pendidikan, 21(1), 110-122.

Yunitasari. (2018). Penerapan Teknik Biblioedukasi untuk Meningkatkan Percaya Diri Kelas VII SMPN 32 Surabaya. Jurnal Bimbingan dan Konseling UNESA, 6(3). 